\title{
INNOVATIVE MULTIMEDIA PROJECT \\ - THE EXEMPLIFICATION OF THE \\ CONCEPT OF TECHNOLOGICAL \\ ENTREPRENEURSHIP
}

\author{
EWA BADZIŃSKA
}

\begin{abstract}
A B S T R A C T
The scientific purpose of the study is an attempted synthesis of the concept of technological entrepreneurship. The cognitive aim of the publication is to present the functionality of an innovative technological solution the uses authorial applications and interactive devices designed and commercialized by the analyzed technology start-up. The application of the empirical method of a case study has made it possible to characterize the essence of technological entrepreneurship and illustrate the progress and development of the studied phenomenon in business practice.

The functionality of an innovative multimedia project has been presented as the exemplification of technological entrepreneurship in cooperation between commercial enterprise and business environment institutions. It has been pointed to measurable economic and social outcomes achieved by the company as a result of conscious implementation of the concept of technological entrepreneurship.

Case studies in the field of technological entrepreneurship should develop the existing theory and provide explanations of the hitherto unrecognized phenomena. The author proposes the understanding of technological entrepreneurship as a process that combines the elements of academic and intellectual entrepreneurship with the entrepreneurship of commercial organizations implementing new technologies in the market environment.

The designed innovative multimedia project supports the management of information for travelers and information regarding fleet management in public transport.
\end{abstract}

KEY WORDS

technological entrepreneurship, technological innovation, multimedia solutions, technology start-up

DOI: 10.1515/emj-2016-0015
Corresponding author:

Ewa Badzińska

Poznan University of Technology Faculty of Engineering Management e-mail: ewa.badzinska@put.poznan.pl

\section{INTRODUCTION}

The concept of technological entrepreneurship is based on increasing innovation, new assets and competitiveness through more efficient use of research results leading to development of products and services. The condition for the creation of this process is effective cooperation between commercial enterprises and business environment institutions in order to diffuse knowledge and scientific potential into commercial solutions in the sphere of technological innovations (Badzińska, 2015, p. 112). This is a creative and innovative ability of knowledgebased companies and an adaptation response to the real business environment (Nacu \& Avasilcăi, 2014). The basis for the development of technological entrepreneurship is formed, therefore, by interactions 
between science, technology and the commercial world (Poznańska, 2010). The author of this paper emphasizes the important role of academic and intellectual entrepreneurship for the development of this complex phenomenon that encompasses multiple disciplines and levels of analysis. Academic entrepreneurship remains the source of technology transfer of both innovative solutions and knowledge into business practice, while the growth of innovative enterprises is a driver of structural changes and causes an increase in regional or even national competitiveness. Technology Start-ups represent the mainstream of academic entrepreneurship and one of the active mechanisms of the commercialization of research results. The ability to implement practical, technical, technological and organizational solutions by the employees of these innovative entities and the ability to cooperate with other companies and business environment institutions undoubtedly prove their competitive advantage (Badzińska, 2014, p. 14).

The scientific purpose of the study is an attempted synthesis of the concept of technological entrepreneurship. The attention was focused on the interpretation of the term and the multidimensionality of this phenomenon. The empirical part of the paper is based on a case study using an example of the technology start-up Glip Ltd. The application of this empirical method has made it possible to characterize the essence of technological entrepreneurship and illustrate the progress and development of the studied phenomenon in business practice. The cognitive aim of the publication is to present the functionality of an innovative technological solution - a multimedia bus stop. The innovative design uses authorial applications and interactive devices designed and commercialized by the analyzed technology start-up. It has been pointed to measurable economic and social outcomes achieved by the company as a result of conscious implementation of the concept of technological entrepreneurship (including the implementation of practical solutions in the area of ICT, the recognition of customers and the business environment, the rewards for innovativeness, the quality of service and promoting the culture of entrepreneurship).

\section{LITERATURE REVIEW}

The multidimensionality of the phenomenon of technology entrepreneurship raises a number of difficulties in assessing its size and effects. In the literature, the terms: technological entrepreneurship, technology entrepreneurship, technical entrepreneurship and techno-entrepreneurship are used synonymously (Petti, 2012). It is a complex phenomenon that encompasses not only multiple disciplines and levels of analysis to be investigated using different perspectives, but also a case-by-case approach for the analysis to be meaningful. All the activities of this phenomenon relate to the identification of potential entrepreneurial opportunities arising from technological developments, and the exploitation of these opportunities through the successful commercialization of innovative products (Petti, 2012, p. xi). Entrepreneurial opportunities often have to be "created" by using the entrepreneurial imagination to embody human aspirations in concrete products and markets (Venkataraman \& Sarasvathy, 2001).

According to Petti's approach (2009), the concept of technological entrepreneurship incorporates four main sets of activities relating to:

- the pragmatic criterion of availability of data,

- creating new technologies or identify existing technologies (but previously undeveloped),

- the recognition and matching of opportunities arising from the application of these technologies to emerging market needs,

- technology development/application, and business creation.

What distinguishes technology entrepreneurship from other entrepreneurship types is the collaborative experimentation and production of new products, assets, and their attributes, which are related to advances in scientific and technological knowledge and the firm's asset ownership rights (Bailetti, 2012, p. 5). The dominant theme of world articles on technological entrepreneurship focuses on small technology firms and on external factors that influence the formation of technology firms (Bailetti, 2012). Another theme addresses the consequences of technology based business and engineering entrepreneurship (Nicholas \& Armstrong, 2003). An important theme is the interdependence between small-firm initiatives and the external infrastructure that contributes to science and technology advances. This theme describes the systems that support the foundation of new technology firms, establishment of a new technology venture and different types of technical entrepreneurs (Jones-Evans, 1995). Liu et al. (2005) represent ways in which entrepreneurs draw on resources and structures to exploit emerging technology opportunities. The history of technological 
entrepreneurship is strewn with solutions in search of problems (Venkataraman \& Sarasvathy, 2001). The other articles cover topics on: university and business incubators, firm spin-off and technology transfer mechanisms, government programs that support technological entrepreneurship and entrepreneurship education.

The results of research conducted by Bailetti (2012) suggest that the number of scholars contributing to the field of technological entrepreneurship is not large, so it is important to develop the established theory. The author argues that technology entrepreneurship is an investment in a project that assembles and deploys specialized individuals and heterogeneous assets that are intricately related to advances in scientific and technological knowledge for the purpose of creating and capturing value for a firm (Bailetti, 2012, p. 5). In turn, Lindenberg and Foss (2011) contend that technological entrepreneurship is about managing joint exploration and exploitation, where each individual has roles and responsibilities in cooperatively moving forward toward accomplishing shared goals. It focuses on investing in and executing the firms' projects, not just recognizing technology or market opportunities. Technological entrepreneurship is understood, therefore, as a joint-production phenomenon that draws from a team of specialized individuals from multiple domains, some or all of whom become embedded in the technology path they try to shape in real time (Garud \& Karnøe, 2003).

The concept of technological entrepreneurship in Polish literature centres on efforts to connect the scientific potential of universities and research and development centres with capital market institutions and business activities (Flaszewska \& Lachiewicz, 2013, p. 14). It is important to ensure optimal conditions for the commercialization of research results and their usage in enterprises in the form of new products and services through effective collaboration with research centres and the businessrelated sphere. Poznańska (2010) emphasizes that technological entrepreneurship provides more practical usability of research results through an effective collaboration between science, technology and the commercial world. Thus, the concept of technology entrepreneurship makes it possible to describe the phenomenon of increasing innovativeness and competitiveness of enterprises through a more efficient use of research results and the potential of scientific institutions and enterprises. The transfer of knowledge to private companies increases their productivity and, consequently, increases investment and employment also in the areas of high technology (Banerski et al., 2009).

Technological entrepreneurship, which must be combined with innovativeness, is an ability to allocate resources efficiently and contains an element of efficiency, as well as the time factor, under the influence of which the shape of the optimum configuration of competitive advantages shifts. The development and implementation of innovations require cooperation with the institutions of business environment, including those that provide funding for such projects. In this respect, technological entrepreneurship is related to the basic pillars of knowledge-based economy (Lachiewicz \& Matejun, 2010 , p. 189). A special role is played here by business ecosystem, namely a wide range of cooperation ranging from consortia or research centres, through consultancy, organizational, funding and infrastructure services, up to relations with business environment institutions in the field of incubation (Badzińska, 2014, p. 28). Innovative companies recognize the importance of effective knowledge management, which constitutes an essential and dominant element in the entire innovation process. It is also important to enrich internal knowledge resources (which constitute the innovative potential of enterprises) with the external ones. There is a close relationship between an innovative potential and activity in this area and the quantity and the quality of knowledge resources accumulated by the company (Kurowska-Pysz, 2012, p. 519).

Technological entrepreneurship is in its essence based precisely on the cooperation of companies with both the science sector and the business environment. Moreover, the technological entrepreneurship formula combines both intellectual entrepreneurship and academic entrepreneurship. Here are taken into consideration spin-offs, also known as professorial or academic companies, as well as technology start-ups with academic origin. Academic entrepreneurship is an expression of new jobs and opportunities that open up for college community and research and development sector and is a manifestation of intellectual entrepreneurship. In Polish literature Kwiatkowski (2000) coined the term intellectual entrepreneurship to describe the creation of the material wealth of immaterial knowledge.

The author of this paper proposes the understanding of technological entrepreneurship as a process that combines the elements of academic and intellectual entrepreneurship with the 
entrepreneurship of commercial organizations owners, managers and employees implementing new technologies and innovative business solutions in the market environment. Case studies in the field of technological entrepreneurship should develop the existing theory and provide explanations of the hitherto unrecognized phenomena. This paper may provide a starting point for an in-depth empirical research and contribution to the discussion on the methodological dilemmas associated with conducting research in the area of technology entrepreneurship.

\section{RESEACH METHODS}

The cognitive aim of this research is to identify and analyze the qualitative functionality of the innovative ICT project, which is an example of technological innovation implemented within the concept of technological entrepreneurship. The subject of the research is a knowledge-based small company from the IT industry - Glip Ltd. The study is empirical in its nature. Primary data acted as a basis to identify the functionality of the multimedia bus stop and it was assessed from the point of view of the benefits for the user (both passengers and public transport companies). The wide problem area of entrepreneurship requires the acceptance of the limitations of the study area. The empirical method makes use of a case study involving the analysis of processes implemented in the selected enterprise (Dyer \& Nobeoka, 2000). The rationale for the use of the case study is its usefulness related to the timeliness of technological entrepreneurship phenomenon and the dynamism of its effects. There is a need to conduct a practice-oriented empirical research for better understanding of reality and to help managers choose their own path (Czakon, 2011). The applied case study has helped to recognize the analyzed phenomenon under real conditions (Yin, 1984), and its purpose has been practical orientation (executive research) of the concept of technological entrepreneurship.

The case study should be a clear example to illustrate the studied correctness (Flyvberg, 2004). The purposeful selection of Glip technology start-up resulted from the pragmatic criterion of availability of data, clarity of the explained phenomenon of technological entrepreneurship, and the observed determinants of technological innovation. The above criteria lead to the conclusion that a single case study would help to attain the objectives of research. The necessity to confront a variety of data sources forced the application of the principle of triangulation (Nazarko \& Ejdys, 2011; Nazarko, 2013):

- qualitative data was obtained from direct (indepth) interview conducted with the owner of the analyzed enterprise, who is responsible for innovation management. A semi-structured interview questionnaire was prepared;

- to expand the database on the company, an analysis of materials from the available secondary sources was also conducted. They included websites, publications and customers' opinions on opineo.pl website;

- an important source of data was the information obtained from Poznan Science and Technology Park of Adam Mickiewicz University Foundation, which is a strategic shareholder of the company.

The author adopted an iterative procedure, in which the stage of verification of data gathering tools is repeated because of the information obtained or problems encountered. The confrontation of multiple data sources justifies the cyclical nature of data collection procedures in the case under examination. Both descriptive and explanatory techniques were used in the presented case study. The obtained quantitative and qualitative data were the basis for creating the characteristics of the innovative ICT project. The multimedia bus stop's diagnosed functionality was presented in a synthetic way.

\section{RESEARCH RESULTS}

Glip Ltd. is a young Polish company manufacturing multimedia touch platforms (Glip Multitouch Solutions, 2013). The founders (two men) of the technology start-up are graduates of the Poznan University of Technology, who, on the basis of interdisciplinary knowledge and experience related to the IT industry and economics, have created a modern business model. The company has been on the market since 2013 and currently employs 8 fulltime workers. In its solutions the company uses modern tools of interactive communication and focuses on the customization of services dedicated to individual customer needs. Glip offers equipment based on the technology of touch, motion detection and holographic projection. The products are dedicated for business customers, cultural and educational institutions and local government units.

An important aspect in the development of technological entrepreneurship is to create an attitude 
of openness among employees regarding knowledge, study the environment in terms of demand for new ICT solutions and look for external sources of information to fill gaps in intellectual resources. In this context, the important role is played by cooperation with selected research institutions and organizations supporting technology transfer. Among the activities undertaken by the company in the field of cooperation with the business ecosystem it is necessary to mention strict scientific and research cooperation between Glip and Poznan Science and Technology Park of Adam Mickiewicz University Foundation. The project called InQbator Seed co-financed by the European Union under the Innovative Economy Operational Programme aided the company in 2013 with the amount of 500.000 PLN (Mam Startup, 2013). It was an important financial aid determining the development of the young technology startup. The funds have enabled further research and progress on the construction of largeformat touch surfaces and specialized software.

Another example of the implementation of technological entrepreneurship by the company is taking part in the prestigious competition called Poznan Leader of Entrepreneurship 2014 in the category Startup 2014. The competition is organized jointly by Poznan City Hall and County Office and is designed to support outstanding enterprises from the SME sector which have been building their strong market position. Technological innovations and the entrepreneurship of young people employed by Glip were fundamental for the company to win first place in the Poznan Leader of Entrepreneurship 2014 competition (Winner..., 2015). In 2014, Glip also won the VII edition of the Award of the Marshal of Greater Poland „,i-Greater Poland - The Innovative for Greater Poland". This is a special award for entrepreneurs who, through their creativity and openness to new scientific thought, bring innovative solutions to the market. The cooperation with the institutions of business environment in consulting, organizing and financing innovative ICT solutions constitute for the company the condition for development.

The innovative multimedia project is a modern media bus stop with GlipTable at its core. The solution is dedicated to companies managing public transport. Touch screens, installed in the shelter and authorial applications developed by Glip, are the first such solutions in Poland in the area of public transport (Fijałkowski, 2014; Bełcik, 2014). In the opinion of its makers the purpose of the designed solution is to optimize the distribution of information for travelers and information regarding fleet management in public transport. The multimedia bus stop was presented by Glip during Gmina 2014 fair (in October) at Poznan International Fair (Fig. 1).

This innovative solution was met with positive
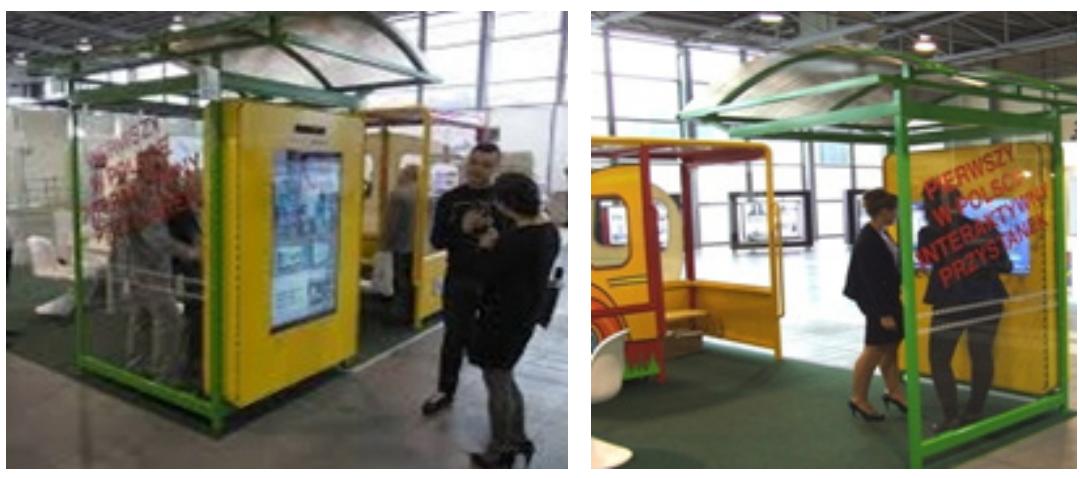
governments, media and technology industry representatives (Janik, 2014). Glip has introduced several modifications to its touch surfaces, providing them with new functionalities and adapting them to modern urban spaces. Below are the synthetically diagnosed seven functionalities of the multimedia bus stop:

- Informative function. The innovative technological solution takes the form of an interactive City Light showcase installed at bus stop shelters. Authorial applications are tailored to the needs of public transport users. The creators of the project have set themselves the goal of creating both modern and quick access to the current information regarding the conurbation to make it easier for commuters to use public transport and get around the city. The designed bus stop has an external and internal media screens with both touch and movement recognition systems. The internal one is intended for services and applications directly associated with travelers (Fig. 2). In addition to basic information such as timetables, route change information, or the means of transport crossing sketch, the screens can be equipped with additional data and entertainment applications with an ability to carry out promotional activities; 
- Promotional function. Based on the information obtained during the direct interview the screens can serve publicity purposes. Additional features include a city map and an interactive guide to the sights of the city and the information about cultural events. Another advantage of this innovative solution is an electronic bulletin board - especially attractive for local advertisers;

- Text magnifying function. There is an option to install a function to magnify text in the screens. It is particularly useful for people with poor eyesight, but also to magnify the object or destination;

- Sign language translator. A sign language translator has been installed for the deaf-mute people. With an application created by Migam.org service travelers can translate the timetable and communicate with others. A camera installed inside the shelter, in addition to the safety aspect, can be helpful if someone needs to call for help;

- The function of planning a route to an address and to a point. In order to improve the updating of timetables and the download of current information about the selected connections, cooperation with City-Nav has been undertaken. This company is the creator of "jakdojade.pl", which is very popular in Poland. It is an innovative public transport planner that allows people to check the timetable, the number of stops and to plan an optimal route (City Navigation Systems, 2011). Thanks to the integration of the bus stop with ,jakdojade.pl" public transport travelers gain an ability to easily set their route on an address and an exact point. It is a valuable functionality from the perspective of tourists;

- The function of updating the timetable remotely. An important advantage of the bus stop is its ability to remotely update the timetable by transport companies. In a case of unforeseen events in the traffic, an administrator can display specific messages on the screen.

functionality greatly simplifies data management and Fig. 2. Services and applications available with GlipTable also makes it Source: (http://startup.poznan.pl, 04.03.2015).

possible to generate
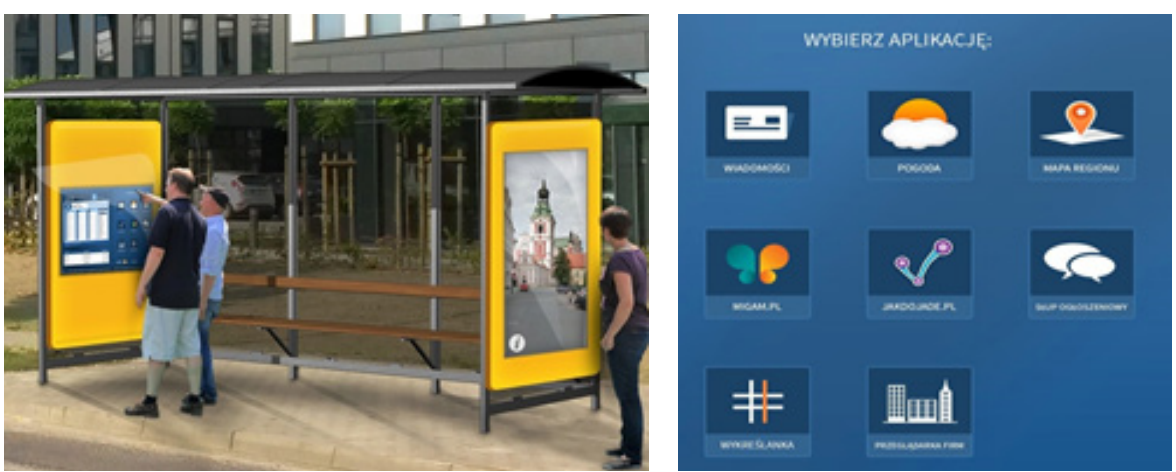

- Advertising function. The outer part of the interactive stop is a medium of commercial advertising activities. The authors of the ICT project assume that the advertising space on the external screen will be a valuable tool allowing shelter owners to amortize costs associated with its purchase. Moreover, an interactive screen equipped with touch, characters or gestures recognition system (Kinect) provides advertisers with a broad context for the application and the opportunity to create interesting promotional campaigns. A camera, motion sensors and an electronic management system all allow its users to customize the message to the target audience. In addition, the announcement time and its location may change several times a day depending on the advertiser's requirements. Glip also offers individual IT, graphics and marketing solutions tailored to the needs of the customer. The innovative product provides its users with a number of benefits so far inaccessible in such a form and on such a scale. This interactive bus stop is a new promotional tool, which will certainly be an interesting alternative to traditional outdoor media. savings in case of

periodic changes to timetables. Introducing changes to timetables at individual stops can be done remotely without any need for time-
As claimed by the initiators and creators of this innovative solution, modern technology and information-advertising applications are to make urban 
bus stops more attractive and also carry economic benefits for urban transport companies. The type and the complexity of applications will determine the cost of the shelter. In case of a successful implementation of the project, Glip will act as manufacturer and supplier of software, providing IT support in the processes related to the implementation and coordination of the undertaken collaboration.

\section{DISCUSSION OF THE RESULTS}

Technology development is considered as a measure of the success of entrepreneurs who initiate the process of commercialization. In order to develop technological entrepreneurship, entrepreneurs should establish lasting relationships with scientists, which could be based on mutual motivation to study and to take risks while conducting business activities. The phenomenon of technological entrepreneurship applies particularly to small and medium-sized hightech enterprises. They work in such areas as biotechnology, electronics, nanotechnology, information technology, etc. These entities are characterized by a tendency to innovate and are very active in launching new products and services. Aiming to develop their own technological and innovative facilities, they seek access to valuable resources of knowledge. If the company's own intellectual assets are not sufficient, there arises a need for knowledge transfer from the environment and to obtain information which is the most valuable for the needs of enterprises. It is important to be aware of support institutions and be able to draw relevant information, establish contacts with the sphere of scientific research and build networks for the exchange of knowledge between companies and the environment. Technological entrepreneurship is in its essence based precisely on the cooperation of companies with both the science sector and the business environment. Furthermore, the issue of project knowledge management is of high significance for companies operating in the multi-project environment, as there are numerous sources of knowledge which can be applied to ongoing projects. The continuous progress in the planning and execution of projects can be used to indicate areas for potential improvement and support the decision makers where and when to invest limited funds (Spałek, 2014, p. 164).

Equipment and authorial applications created by
Glip support interactive and engaging business communication, creating new customer needs and setting trends in the corporate image management. The company uses innovative solutions in its products, which are based on knowledge, latest technologies and the experience of IT professionals. A team of young entrepreneurs working for Glip is currently planning more innovative business solutions and applications for their devices, not only in the arrangement of urban space. Through dedicated applications, providing customers with a series of comprehensive tools and individual counseling, the company helps to identify and create opportunities for other economic operators. The involvement of the team, a shared vision of the present and the future of the company, the focus on technological innovations and paying attention to customer satisfaction constitute the basis for the development of the organization and directly translate into market success.

The search for savings is one of the major problems of modern public transport companies. The use of modern ICT solutions and telematics systems, which allow the processing of data or instance available via GPS make it possible to more effectively manage enterprise communication. The implementation of the solution - a media bus stop which earns its own money - should bring tangible economic benefits for the enterprise and improve the quality of communication services.

\section{CONCLUSIONS}

For the development of technological entrepreneurship in companies it is important to develop a strategy with the use of technical and intellectual capacity of organizations. One cannot miss here the external environmental factors related to technological entrepreneurship and its support instruments. Important stimuli are both the local climate and the commitment of local government and business institutions. Moreover, it is necessary to identify and eliminate barriers that may limit the implementation of the described concept. Supporting the development of innovative academic companies and accelerating the process of commercialization of intellectual property may significantly contribute to the further integration of academics and practitioners.

The rationale for conducting research on case studies is the timeliness of the issue and the need to orient the practice for a better understanding of the 
phenomena of modern economic reality. Case studies in the field of technological entrepreneurship should develop the existing theory and provide explanations of the hitherto unrecognized phenomena. In addition, they will facilitate understanding and support development of the analyzed processes, taking into account the economic, social and cultural characteristics of the region. The presented case study can be a starting point for an in-depth empirical theory-creating research (for instance the multiplecase studies approach was followed by Yin (1994), and Eisenhardt and Graebner (2007) recommendations), providing hypotheses for quantitative research, or making room for exploration that was previously perceived differently or simply overlooked. The findings of case studies can help practitioners in designing processes more adapted to the characteristics of their projects and contingencies, which may lead to a better allocation of resources and better efficiency in general (Salerno et al., 2015).

Despite the fact that the research is based on a single case study, there are some interesting implications for business practice. Comprehensive and efficient management of a fleet of vehicles in a transport company requires today the implementation of modern ICT solutions. The existing problems of public transport and the effects associated with excessive traffic all require innovative solutions for sustainable mobility in the future (Telematik im Verkehr, 2015). The implementation of innovative multimedia bus stop project in conjunction with telematics systems to enable the processing of data (information generated by onboard equipment installed in vehicles, and from the road infrastructure i.e. ITS systems in cities) provide an opportunity for more effective management of the enterprise communication through effective management of its manpower and equipment. The bus stop is to be friendly to tourists, the elderly, and the disabled and, above all, provide the most recent information. Information management and its quality, timeliness and flow rate often account for competitive advantage. The co-founder of the innovative multimedia bus stop project stresses that the solution is ahead of the boom, which will eventually come in connection with the introduction of interactive devices in the urban space.

The implementation of modern telematics solutions undoubtedly supports the decision-making process in fleet management. There is a need for rational use of existing transport infrastructure and improving the flows to increase economic efficiency, safety of passengers and respect for the environment. Moreover, new information and communication technologies determine the need for new organizational solutions, also within public transport companies. Technological innovations should contribute to the increase of their users' life quality and a wider use of economic and social potential of the region.

\section{LITERATURE}

Badzińska, E. (2014). Indywidualizacja rozwiązań ICT w praktyce gospodarczej na przykładzie start-upów akademickich [Individualization of ICT solutions in business practice on the example of academic startups]. Business Informatics, 2(32), 24-32.

Badzińska, E. (2014). The competitive advantage of academic start-ups in innovative business solutions. In A. Skrzypek (Ed.), Knowledge, innovation and quality as factors of the success in the new economy (pp. 13-24). Lublin, Poland: Publishing House University of Maria Curie-Skłodowska in Lublin.

Badzińska, E. (2015). Technological entrepreneurship as a condition for the transfer of innovative solutions to business practice. 16th EBES Conference - Istanbul Program and abstract book. Istanbul, Turkey: EBES Publications.

Bailetti, T. (2012). Technology Entrepreneurship: Overview, Definition, and Distinctive Aspects. Technology Innovation Management Review, 2(2), 5-12.

Banerski, G., Gryzik, A., Matusiak, K. B., Mażewska, M., \& Stawasz, E. (2009). Przedsiębiorczość akademicka. Raport $z$ badania [Academic Entrepreneurship. Research Report]. Warszawa, Poland: PARP.

Bełcik, A. (2014, October 13). Przystanki naszpikowane technologia [Bus stops packed with technology]. Puls Biznesu.

City Navigation Systems (2011). Retrieved from http://www.city-nav.com

Czakon, W. (2011). Zastosowanie studiów przypadku $\mathrm{w}$ badaniach nauk o zarządzaniu [Case studies in management science research]. In W. Czakon (Ed.), Podstawy metodologii badań w naukach o zarzadzaniu [Fundamentals of research methodology in management science], (pp. 46-63). Warszawa, Poland: Wolters Kluwer Business.

Dyer, J., \& Nobeoka, K. (2000). Creating and Managing a High Performance Knowledge-Sharing Network: The Toyota Case. Strategic Management Journal, Special Issue: Strategic Networks, 21(3), 345-367. doi:

10.1002/(SICI)1097-0266(200003)21:3<345::AIDSMJ96>3.0.CO;2-N

Eisenhardt, K. M., \& Graebner, M. E. (2007). Theory building from cases: opportunities and challenges. Academy of Management Journal, 50(1), 25-32. 
Fijałkowski, P. (2014, October 18). Multimedialny przystanek stanie $w$ Poznaniu [Multimedia bus stop in Poznan]. Gazeta Wyborcza.

Flaszewska, S., \& Lachiewicz, S. (2013). Przedsiębiorczość technologiczna we współczesnej gospodarce [Technological Entrepreneurship in the modern economy]. In S. Lachiewicz, M. Matejun, \& A. Walecka (Eds.), Przedsiębiorczość technologiczna $w$ matych $i$ średnich firmach [Technological entrepreneurship in small and medium-sized enterprises], (pp. 11-24). Warszawa, Poland: Wydawnictwo WNT.

Flyvbjerg, B. (2004). Five Misunderstandings About CaseStudy Research. In C. Seale, G. Gobo, J. F. Gubrium, \& D. Silverman (Eds.), Qualitative Research Practice (pp. 390-404). London, Great Britain; Thousand Oaks, USA: Sage Publications.

Foss, N. J., \& Klein, P. G. (2004). Entrepreneurship and the Economic Theory of the Firm: Any Gains from Trade? Working Paper No. 11. Copenhagen, Denmark:Copenhagen Business School CKG.

Friedrich Ebert Stiftung (2001). Telematik im Verkehr: Probleme und Perspektiven. Retrieved from http://www.fes.de/fulltext/fo-wirtschaft/00345.htm

Garud, R., \& Karnøe, P. (2003). Bricolage versus breakthrough: distributed and embedded agency in technology entrepreneurship. Research Policy, 32(2), 277-300. doi:10.1016/S0048-7333(02)00100-2

Glip Multitouch Solutions (2013). Retrieved from http://glip.pl/index.html

Janik, M. (2014). Interaktywny przystanek [Interactive bus stop]. Retrieved from http://www.magazyngmina.pl/ $\mathrm{i} \mathrm{n}$ d e $\mathrm{x}$. p h p ? o p t i o n = c o m k2\&view=item\&id=902:interaktywny-przystanek

Jones-Evans, D. (1995). A typology of technology-based entrepreneurs: A model based on previous occupational background. International Journal of Entrepreneurial Behavior \& Research, 1(1), 26-47. doi: http://dx.doi.org/10.1108/13552559510079751

Kurowska-Pysz, J. (2012). Miejsce wiedzy w rozwoju innowacyjnych firm - szanse i bariery współpracy ośrodków akademickich i przedsiębiorstw [Knowledge in the development of innovative companies - opportunities and barriers between universities and enterprises]. Studia Ekonomiczne Regionu Łódzkiego, Special Issue, 519-535.

Kwiatkowski, S. (2000). Przedsiębiorczość intelektualna. Bogactwo $z$ wiedzy [Intellectual Entrepreneurship. Wealth of knowledge]. Warszawa, Poland: PWN.

Lachiewicz, S., \& Matejun, M. (2010). The role of External Environment in Creating Technology Entrepreneurship in Small and Medium-Sized Enterprises. Management, 14(1), 187-202.

Lindenberg, S., \& Foss, N. J. (2011). Managing joint production motivation: The role of goal framing and governance mechanisms. Academy of Management Review, 36(3), 500-525.

Liu, T. H., Chu, Y. Y., Hung, S. Ch., \& Wu, S. Y. (2005). Technology entrepreneurial styles: a comparison of UMC and TSMC. International Journal of Technology Management, 29(1/2), 92-115.
Mam Startup (2013). InQbator Seed inwestuje w interaktywne stoly $z$ Poznania [InQbator Seed invests in interactive tables from Poznan]. Retrieved from http:// mamstartup.pl/pressroom/4583/inqbator-seedinwestuje-w-interaktywne-stoly-z-poznania

Nacu, C. M., \& Avasilcăi, S. (2014). Technological ecopreneurship: conceptual approaches. Procedia Social and Behavioral Sciences, 124, 229-235. doi: 10.1016/j.sbspro.2014.02.481

Nazarko, J. (2013). Regionalny foresight gospodarczy. Metodologia i instrumentarium badawcze [Regional economic foresight. Reaserch methodology and instrumentarium]. Warszawa, Poland: ZPWiM.

Nazarko, J., \& Ejdys, J. (Eds.). (2011). Metodologia $i$ procedury badawcze $w$ projekcie Foresight Technologiczny NT for Podlaskie 2020: regionalna strategia rozwoju nanotechnologii [The methodology and research procedures in Technological NT Foresight Project for Podlaskie 2020: Regional development strategy for nanotechnology]. Białystok, Poland: Oficyna Wydawnicza Politechniki Białostockiej.

Petti, C. (Ed.). (2009). Cases in technological entrepreneurship: Converting ideas into value. Northampton, MA: Edward Elgar Publishing.

Petti, C. (Ed.). (2012). Technological Entrepreneurship in China: How Does it Work? Northampton, MA: Edward Elgar Publishing.

Poznan Leader of Entrepreneurship (2014). Retrieved from http://www.poznan.pl/mim/lidermsp/poznanscyliderzy-przedsiebiorczosci,p,9019,9025.html

Poznańska, K. (2010). Przedsiębiorczość technologiczna. Retrieved from http://www.pol-nord.eu/IP_ Workshop/Prof._Krystyna_Poznanska_Przedsiebiorczosc_technologiczna.pdf

Salerno, M. S., Vasconcelos Gomes de, L. A., Silva da, D. O., Bagno, R. B., \& Freitas, S. L. T. U. (2015). Innovation processes: Which process for which project? Technovation, 35, 59-70. doi: $10.1016 / \mathrm{j}$. technovation.2014.07.012

Spalek, S. (2014). Assessing Project Management Maturity in the area of knowledge management in select companies. International Journal of Economics, Finance and Management Sciences, 2(2), 164-170. doi: 10.11648/j.ijefm.20140202.18

Venkataraman, S., \& Sarasvathy, D. (2001). Strategy and Entrepreneurship: Outlines of an Untold Story. Working Paper 01-06. Charlottesville, USA: Darden Business School.

Winner in the category Start-up (2014). Retrieved from http://www.poznan.pl/mim/main/laureat-wkategorii-start-up-glip-sp-z-o-o,poi,4680/laureat-wkategorii-start-up-glip-sp-z-o-o,55210.html

Yin, R. K. (1994). Case Study Research: Design and Methods. Thousand Oaks, USA: Sage Publications. 